\title{
EVALUATION OF THE LEVEL OF LENGTH OF EATING TIME, CHEWING AND PARAMETERS OF DAILY INCREASED ACTIVITY DEPENDING ON THE BREED, THE LACTATION NUMBER AND THE PERIOD OF THE YEAR
}

\author{
Radim Codl¹, Jaromír Ducháček ${ }^{1}$, Jan Pytlík¹, Luděk Stádník¹, \\ Mojmír Vacek ${ }^{1}$, Marek Vrhel ${ }^{1}$

\begin{abstract}
${ }^{1}$ Department of Animal Science, Faculty of Agrobiology, Food and Natural Resources, Czech University of Life Sciences Prague, Kamýcká 129, 165 00, Prague-Suchdol, Czech Republic
\end{abstract}

Link to this article: https://doi.org/10.11118/actaun202068040659

Received: 27. 7. 2020, Accepted: 17. 8. 2020

To cite this article: CODL RADIM, DUCHÁČEK JAROMÍR, PYTLÍK JAN, STÁDNÍK LUDĚK, VACEK MOJMÍR, VRHEL MAREK. 2020. Evaluation of the Level of Length of Eating Time, Chewing and Parameters of Daily Increased Activity Depending on the Breed, the Lactation Number and the Period of the Year. Acta Universitatis Agriculturae et Silviculturae Mendelianae Brunensis, 68(4): 659-667.

\begin{abstract}
Eating time, rumination and activity is affected by many factors. Evaluation of the parameters obtained from Vitalimeter 5P was performed on 719 dairy cows Czech fleckvieh cattle and Holstein cattle and their hybrids within one farm. Data collecting took place for one year. As part of a detailed evaluation using the GLM procedure, the lactation number, the period of the year and the pedigree $(P<0.001)$ had a significant effect on the time of rumination, eating, increased activity and the sum of activities. The highest values in all monitored parameters were reached by $\mathrm{H}$ 51-87. Within the effect of the lactation number was evident a certain discrepancy when the longest eating time was observed in cows at the first lactation (293.20 min.), while the longest rumination time in cows at 3 , resp. 4 and further lactation (484.82 and $482.46 \mathrm{~min}$, respectively). The lowest values were monitored for these two parameters in exactly the opposite order, the lowest eating time in older cows and the shortest rumination time in the youngest cows. Results of evaluated periods of the years confirmed mainly the differences in the time of eating and rumination in the summer months compared to the rest of the year $(\mathrm{P}<0.01)$. These results, both individually and within the interactions of factors, confirm the effects of the body framework in the case of breeds, the age of the animals within the lactation order and the importance of assessing heat stress in assessing the effect of the year.
\end{abstract}

Keywords: dairy cow, activity, chewing, eating, season

\section{INTRODUCTION}

Monitoring the time of eating and rumination is becoming a trend in modern dairy farming. Feed intake and rumination time are affected by a number of effects. During the year, the rumination time and thus the performance of dairy cows demonstrably change. These indicators and especially productivity is an important parameter for farmers in the economy of breeding (Krpalkova et al., 2016). For this reason, it is necessary to explain the effects on the performance of dairy cows during the year. It is important to create suitable conditions for dairy cows throughout the year, so as to ensure consistent 
milk production throughout the year. During the summer, dairy cows suffer most from heat stress, which is manifested by a reduction in rumination time or a reduction in rumination comfort (Acatinai et al., 2010). This phenomenon can be prevented by the stable condition by using forced ventilation and evaporation during the summer days when the dairy cows suffer from heat stress. Heat stress has the greatest impact on high-production dairy cows compared to low- producing dairy cows (West et al., 2003), which goes hand in hand with their more intensive metabolism and also with an increase in the lactation number. The decrease in milk yield during heat stress can be up to 25\% (Černý et al., 2016). Due to climate adaptation, European genotypes are more resistant to cold stress (Novák et al., 2002). During these cold months, there is only a minimal decrease in production of about 1-2 l/day (Angrecka and Herbut, 2015). However, during these months, more emphasis is placed on the quality of the feed ration so that dairy cows can compensate for the heat loss caused by the cold (Doležal and Černá, 2003). The lactation number also has a significant effect on the production of the total amount of milk on the farm (Hart et al., 2013) through the percentage of culling and the proportion of dairy cows in higher lactations. The use of dairy cows at higher lactations is a way not only to increase longevity, but also to improve the economy of dairy cattle breeding in the Czech Republic. To our knowledge, this is the first comprehensive study summarizing the relationships between rumination time, eating, increased activity, lactation order, and daily production in crossbreeds of Czech fleckvieh and Holstein cattle throughout the calendar year. The aim of the work was therefore to evaluate the relationships between these described parameters and describe the development of feed intake time, rumination, increased activity and total duration of all activities depending on the breed, the lactation number and the period of the year.

\section{MATERIALS AND METHODS}

\section{Description of Evaluated Farms and Animals}

The monitoring was carried out on a farm in the Olomouc region, which is at an altitude of $458 \mathrm{~m}$ above sea level. The farm is focused on breeding dairy crossbreeds of Czech fleckvieh cattle and Holstein cattle. 719 cows entered the evaluation, which entered the database in different months of the data collection, and therefore there was a different number of observations for each dairy cow (approximately 251 records per animal). In the monitored company, an average milk yield of $7247 \mathrm{~kg}$ of milk was achieved for standardized lactation with a fat content of $4.38 \%$ and a protein content of $3.66 \%$. Vitalimeter 5P neck responders (Farmtec a.s.) were used to identify rumination time and eating time.
The dairy cows were housed in four freestall barns. The boxes with straw bedding. Milking took place twice a day in the fish bone milking parlor $2 \times 16$ stalls with a fast departure. The milking parlor technology automatically performs identification of dairy cows, measurement of milk yield and milk conductivity. On the evaluated farm, the animals are fed with a mixed feed ration (TMR) which is mixed for each production group separately. The classification of dairy cows into groups was based on the degree, lactation number and with regard to the milk yield of dairy cows, or according to health status. For dairy cows, 5 feed rations are implemented daily: TMR for weaning, TMR for lactating dairy cows, TMR for end of lactation, TMR for dry cows and TMR for pre-fresh. A feed wagon with a strain gauge is used to load the feed, which enables precise weighing of the necessary components. The feed is established twice a day, always in the morning and in the afternoon. The food is added as needed throughout the day.

\section{Data Description}

A database with calved animals throughout 2018 was analyzed. The database included data on eating and rumination time and increased activity from the Vitalitmeter 5P. Unlike rumination and eating, increased activity was recorded as the number of increased activity events because it was recorded only when the animal moved and made a movement with an acceleration greater than $0.7 \mathrm{~g}$. Daily milking, which were automatically recorded at the milking parlor and other parameters of dairy cows (pedigree, month of evaluation and lactation number) were added to the data afterwards. Obviously erroneous data were excluded from the evaluation, when on some days there were zero records of activities from the Vitalimeter 5P. In addition, the data were adjusted for external measured values for rumination below 300 and over 960 minutes for eating below 120 and over 420 minutes. Discarded observations accounted for up to $8 \%$ of all records.

\section{Statistic Evaluation}

The data were evaluated with statistical software SAS 9.3. (SAS/STAT® 9.3, 2011). Procedure UNIVARIATE and MEANS were used for basic statistics parameters evaluation. Relationships between evaluated parameters was computed with CORR procedure. The STEPWISE method and REG procedure was used for selection suitable factors to model equation. GLM procedure was used for main evaluation of feeding time, rumination time, daily milk production. The best model for evaluation was selected in accordance with the values of the Akaike Information Criterion (AIC). The Tukey-Kramer method was used for evaluation of differences of least square means. The model equation used for the evaluation was as follows: 


$$
\begin{aligned}
& \mathrm{Y}_{\mathrm{ijkl}}=\mu+\text { BREED }_{\mathrm{i}}+\text { PARITY }_{\mathrm{j}}+\text { SEASON }_{\mathrm{k}}+ \\
& + \text { BREED } \times \text { PARITY }_{\mathrm{ij}}+\text { BREED } \times \text { SEASON }_{\mathrm{ik}}+ \\
& + \text { PARITY } \times \text { SEASON }_{j \mathrm{k}}+\mathrm{b} 1 *(\text { MILK })+ \\
& +\mathrm{b} 2 *(\mathrm{DIM})+\mathrm{e}_{\mathrm{ijkl}},
\end{aligned}
$$

where:

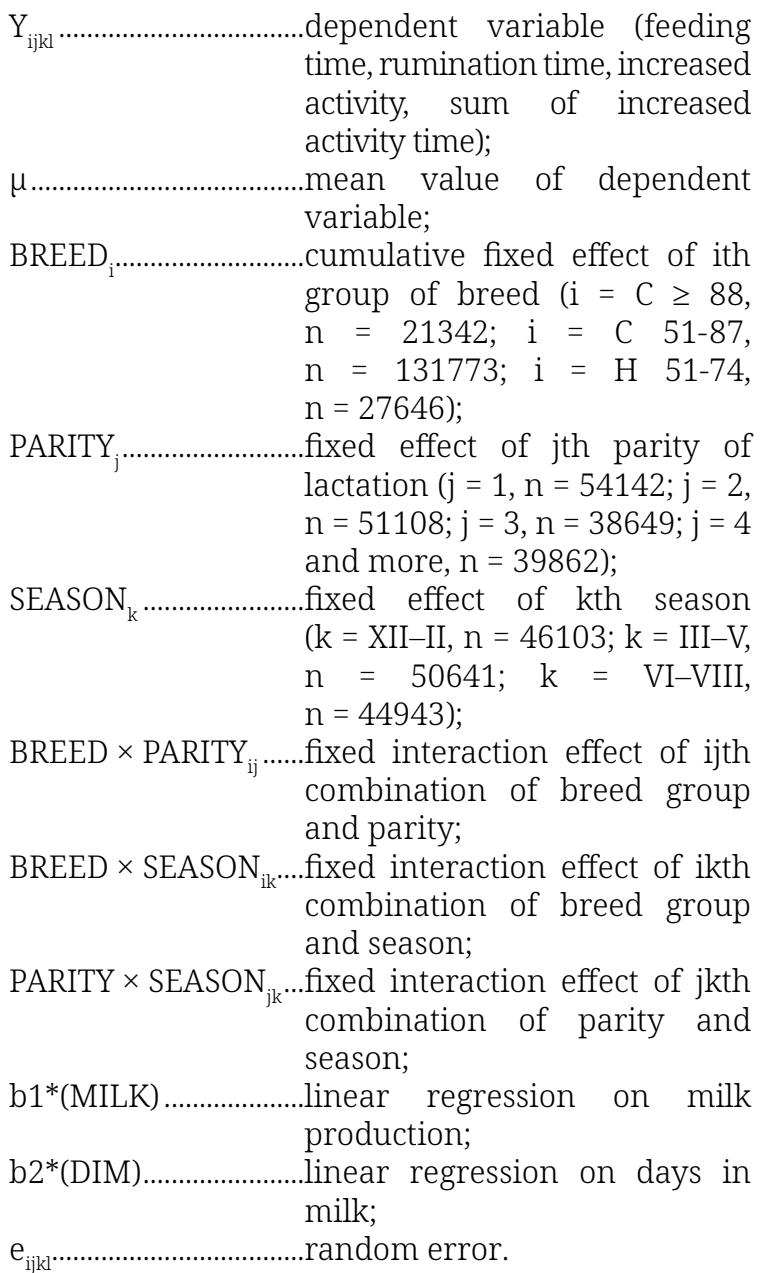

Significance levels $\mathrm{P}<0.05, \mathrm{P}<0.01$, and $\mathrm{P}<0.001$ were used to evaluate the differences between groups.

\section{RESULTS}

Tab. I shows the correlations between the monitored parameters. Weak positive correlations $(\mathrm{r}=0.013$ to $0.122 ; \mathrm{P}<0.001)$ were calculated between eating time and increased activity, resp. day milk yield. Conversely, a negative relationship $(\mathrm{r}=-0.057$ to $-0.221 ; \mathrm{P}<0.001)$ can be described between the time of eating and the lactation number, e.g. days in lactation. The chewing time was weakly correlated with the lactation number, daily milking $(\mathrm{r}=0.071 ; \mathrm{P}<0.001)$. Again, a negative correlation $(r=-0.074$; $\mathrm{P}<0.001$ ) of chewing time to lactation days was observed. Subsequently, the lactation number was moderately correlated with daily milk production $(r=0.261$; $\mathrm{P}<0.001)$. A slightly negative correlation was then calculated between the lactation number and the days of lactation $(\mathrm{r}=-0.084 ; \mathrm{P}<0.001)$. Relatively high negative correlations were then observed between the days of lactation and daily milk $(r=-0.343 \mathrm{P}<0.001)$.

The basic statistically used model equations for the evaluation of the monitored parameters of feed intake and production are given in Tab. II. The model equation was statistically significant $(\mathrm{P}<0.001)$ and explained from 5.9 to $12.3 \%$ of the variability of the monitored parameters. In addition, all the effects used in the model equation were conclusive for all monitored parameters $(\mathrm{P}<0.001)$. The only exceptions in this were the effect of linear regression on milk production in the case of chewing time and breed interaction $\times$ period of the year at the time of feed intake.

The following Tab. III already expresses a detailed evaluation according to the observed effects (breed, parity and season) without interactions. As part of the breed effect, the highest values of feed intake time were recorded in group $\mathrm{H}$ 51-75. This group ate on average 9.48 to 21.58 minutes longer than the other groups $(\mathrm{P}<0.01)$. Statistical evidence $(\mathrm{P}<0.01)$ was also observed during the chewing time. Here in this case the highest value was reached for $\mathrm{H}$ 51-75 (480.15 minutes). Conversely, the lowest value was calculated for C 51-87 (473.73 minutes). Within the increased activity, the highest values were recorded for $\mathrm{H}$ 51-75 (+0.30 to 0.32, $\mathrm{P}<0.01)$. The longest time of all activities was also achieved by $\mathrm{H}$ hybrids (770.08 minutes) due to the longer time of feed intake and chewing. In contrast, the shortest time of all activities was observed for essentially purebred C (743.19 minutes). There were significant differences between the individual groups of animal breeding $(\mathrm{P}<0.01)$.

The effect of lactation order was manifested by a markedly decreasing tendency at the time of feed intake (293.20 to 246.13 minutes, $\mathrm{P}<0.01$ ). On the contrary, a growth trend with the lactation number was recorded for the chewing time. The lowest value was reached in first calves (462.76 minutes), while the highest in cows for 3 lactations (484.82 minutes). There was a slight decrease in the values of this indicator in cows at 4 and further lactation. Nevertheless, statistically significant differences ( $\mathrm{P}<0.01$ - 0.05) were recorded between all lactation orders. The increased activity indicator had a similar trend with the lactation number as in the case of feed intake. Differences between lactation number ranged from 0.51 to 1.34 ( $\mathrm{P}<0.01$ ). As part of the evaluation of the sum of activities, the highest times were observed in cows on the second lactation (767.35 minutes) and the lowest then on cows on the $4^{\text {th }}$ and subsequent lactations (735.08). Here as well can be seen from Tab. III, there were statistically significant differences $(P<0.01)$.

Seasonality within the calendar year was also reflected in all evaluated parameters of feed intake and activities. The statistically significant highest 
I: Correlations

\begin{tabular}{|c|c|c|c|c|c|c|}
\hline & & Rumination time & Parity & Daily milk production & Milking time & Days in milk \\
\hline \multirow{3}{*}{ Feeding time } & $\mathrm{r}$ & -0.004 & -0.221 & 0.122 & 0.013 & -0.057 \\
\hline & $\mathrm{P}$ & 0.113 & $<0.001$ & $<0.001$ & $<0.001$ & $<0.001$ \\
\hline & $\mathrm{n}$ & 183761 & 183761 & 171235 & 171235 & 183761 \\
\hline \multirow{3}{*}{ Rumination time } & $\mathrm{r}$ & & 0.133 & 0.166 & 0.071 & -0.074 \\
\hline & $\mathrm{P}$ & & $<0.001$ & $<0.001$ & $<0.001$ & $<0.001$ \\
\hline & $\mathrm{n}$ & & 183761 & 171235 & 171235 & 183761 \\
\hline \multirow{3}{*}{ Parity } & $\mathrm{r}$ & & & 0.278 & 0.261 & -0.083 \\
\hline & $\mathrm{P}$ & & & $<0.001$ & $<0.001$ & $<0.001$ \\
\hline & $\mathrm{n}$ & & & 171235 & 171235 & 183761 \\
\hline \multirow{3}{*}{ Daily milk production } & $\mathrm{r}$ & & & & 0.705 & -0.514 \\
\hline & $\mathrm{P}$ & & & & $<0.001$ & $<0.001$ \\
\hline & $\mathrm{n}$ & & & & 171235 & 171235 \\
\hline \multirow{3}{*}{ Milking time } & $\mathrm{r}$ & & & & & -0.343 \\
\hline & $\mathrm{P}$ & & & & & $<0.001$ \\
\hline & $\mathrm{n}$ & & & & & 171235 \\
\hline
\end{tabular}

$\mathrm{r}$ = correlation coefficient; $\mathrm{P}$ = statistical significance; $\mathrm{n}$ = number of observing value

feed intake time (286.58 minutes), but also the surprisingly lowest chewing time (462.41 minutes) can be observed in the period VI-VIII. The statistically significant $(\mathrm{P}<0.01)$ shortest feed intake time was in autumn (IX-XI) and winter months (XII-II) (262.19 and 261.96 minutes, respectively). Within the chewing time, the longest time was recorded in the winter months (XII-II) (483.25 minutes; P < 0.01). The length of the chewing time in spring (III-V) and autumn (IX-XI) did not differ much from the winter months (XII-II) (-1.77 to -5.05 minutes). The increased activity was highest in the summer months (VI-VIII) (7.16). In the autumn and winter months of the calendar year, they hardly differed (6.86 and 6.89, respectively). The demonstrably lowest value of increased activity was calculated but for the summer months (6.58, P < 0.01). Finally, the sum of all activities where the highest value was reached in the spring months (III-V) (767.35 minutes) and the lowest value was in the autumn months (747.25 minutes). All evaluated periods of the calendar year were significantly different $(\mathrm{P}<0.01)$. Fig. 1-3 then express the results for the interactions of the effects of breed group $\times$ parity, breed group $\times$ season and parity $\times$ season. Fig. 1 show that especially the cows on the first lactation in all groups of breeds achieved higher values of feed intake time $(\mathrm{P}<0.01)$. When evaluating the chewing time, it can be seen from Fig. 1 that for $C>88$ and $\mathrm{H}$ 51-75 the longest times were observed in the animals on the third lactation, while in $\mathrm{C}$ 51-87 the highest values were in the animals on the $4^{\text {th }}$ and subsequent lactation. The highest values of the sum of all activities are observable for $C>88$ in cows per 3 lactations, while for $\mathrm{C} 51-87$ the highest value is for cows for 2 lactations and for $\mathrm{H}$ 51-87 heifers. Only in the case of $\mathrm{H}$ hybrids was there a clear trend in the decrease of the sum of activities with the lactation

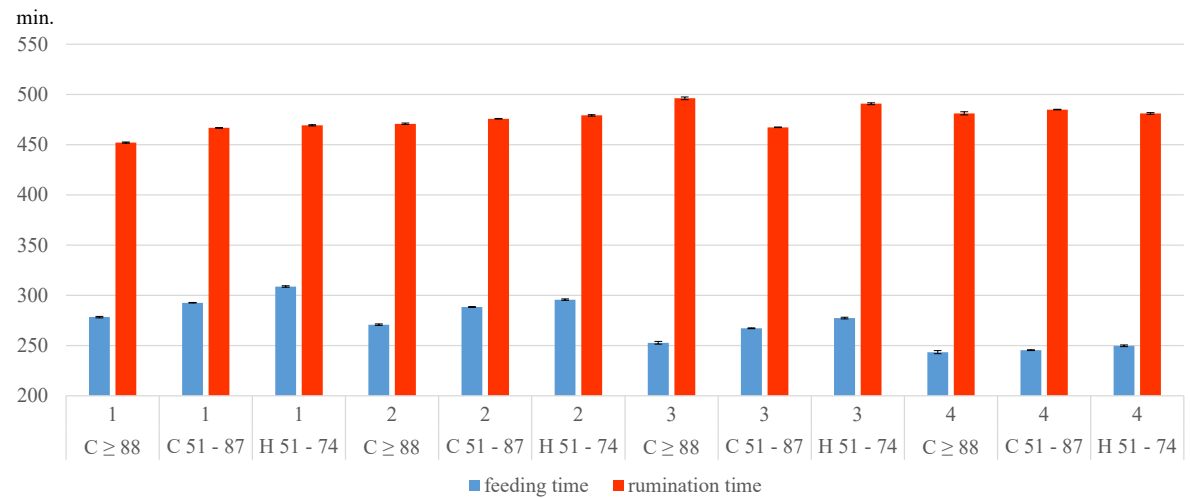

1: Interaction between breed group within lactation number 


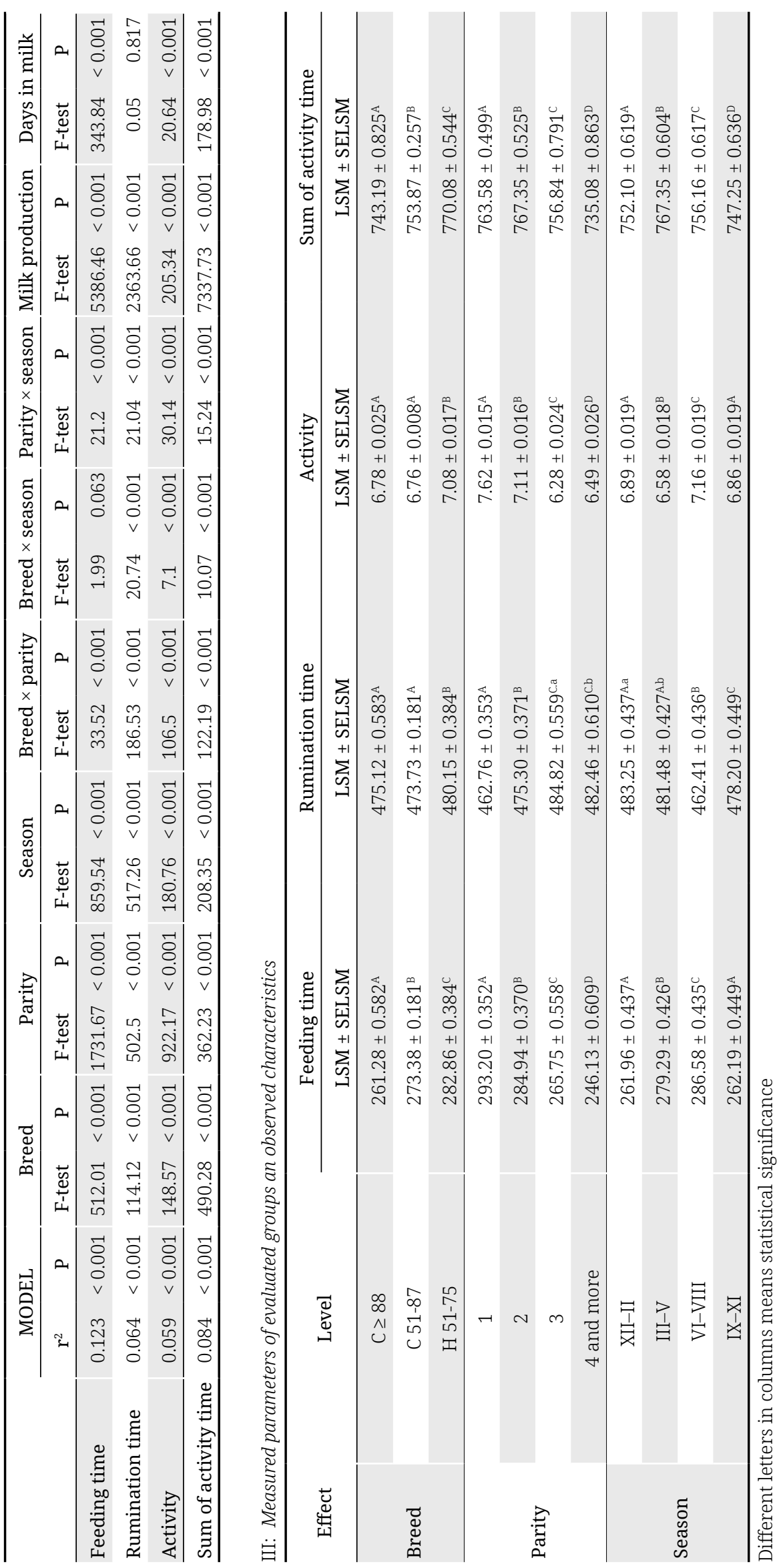




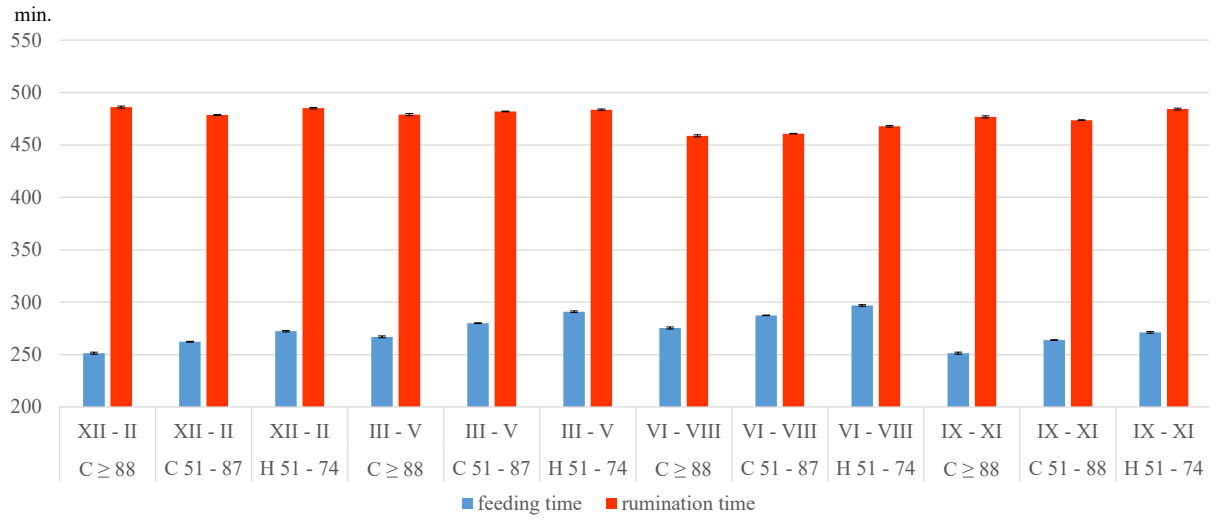

2: Interaction beween breed group within season

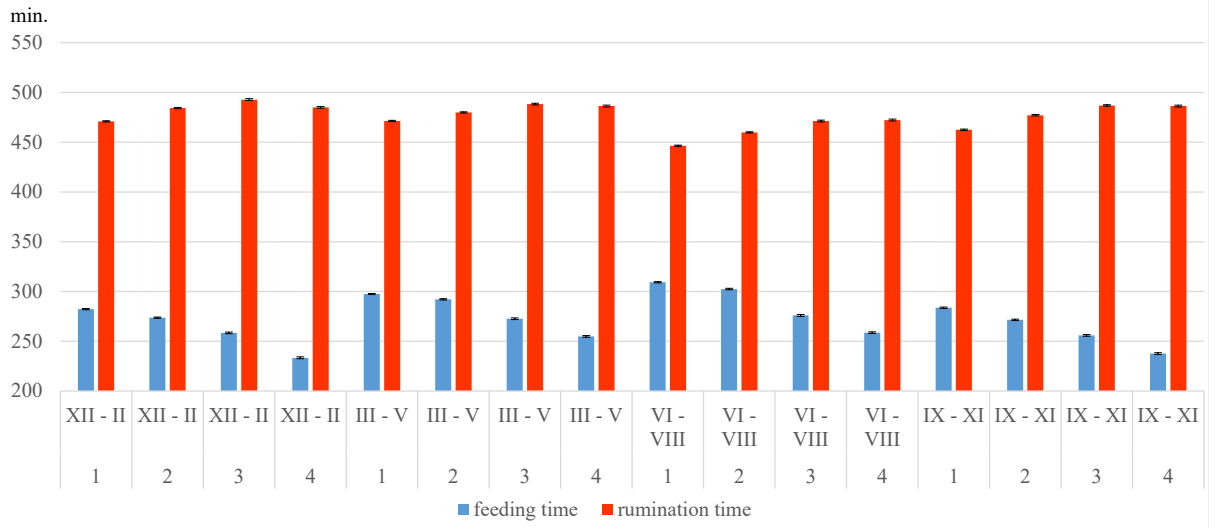

3: Interaction beween lactation number within season

number. The remaining groups tended to increase first with the lactation number and then decrease.

Fig. 2 does not show too significant changes in the time of feed intake within the period and group of breeds. Nevertheless, it can be said that the highest time of feed intake was in the summer months (VI-VIII) $(\mathrm{P}<0.01)$. To evaluate the chewing time within this interaction, it can be stated that each group of breeds has the lowest and highest values in a different period. When comparing the increased activity in Fig. 2 in detail between the groups of breeding affiliation and period, significant differences are evident. For all groups of breeding affiliation, the highest values were evaluated in the period VI to VIII and the lowest on the contrary in the period III to $\mathrm{V}$ within the calendar year $(P<0.01)$. The sum of the time of all activities was finally based on the highest breeding groups of all groups in the period III to $\mathrm{V}$ within the calendar year. Statistically significant $(P<0.05-0.01)$ the lowest values within this parameter and evaluation were achieved in the period IX to XI.

In Fig. 3 we can observe the interaction of parity and season. Cows on the first to fourth and subsequent lactation had a significantly higher feed intake period in the period III-V $(\mathrm{P}<0.01)$. For the period of chewing, there is always a noticeable drop in values in the summer months of the year for all lactation order $(\mathrm{P}<0.01)$. When evaluating the increased activity, no obvious tendencies or trends are evident within this interaction. However, lower values are observed during the spring of the year compared to other periods of the year across lactations. The sum of increased activity times then copied the chewing time with its tendencies. Numerous statistically significant differences ( $P<0.05$ - 0.01) were also observed here.

\section{DISCUSSION}

Between cows of Czech fleckvieh cattle and Holstein cattle, and their hybrids were observed relatively significant differences in the time of feed intake, eating, milk yield. These differences can be explained, among other things, by the heterosis effect. This is confirmed in work Hirooka and Bhuiyan (1995).

The negative correlation between eating time and lactation order is explained by Azizi et al. (2009). Beauchemin et Rode (1994) observed a slower rate of eating compared to older cows and a higher frequency of feed trough visits. This was also confirmed by the results in our work, when the eating time of heifers in our study was on average higher than in cows on 2 and other lactations. Similar results are reported in the study 
by Azizi et al. (2010), when heifers spent a similar amount of time eating 270 to 325 minutes and dairy cows for the third lactation 214 to 264 minutes as dairy cows in our study. The difference between lactations Azizi et al. (2010) attributed to the slower food intake of heifers. These results are further confirmed by other authors (Beauchemin and Rode, 1994; Dado and Allen, 1994; Maekawa et al., 2002, Kowsar et al., 2008). A slightly higher correlation $(\mathrm{r}=0.384)$ than in our study, but also a positive correlation between chewing time and daily milk, is described in the study by Antanatias et al. (2018). Stone et al. (2017) reported a moderate correlation between milk yield and chewing time at $(r=0.22)$ (Antanaitis et al., 2018; Moretti et al., 2017), with our calculated correlations between good chewing and performance is slightly lower $(r=0.166)$.

The negative correlation between chewing and lactation days can be explained by the relationship between chewing time and milk yield. During the early lactation phase in the study (Beauchemin, 1991), dairy cows chewed on average more than 600 minutes per day with a maximum chewing time of $685 \mathrm{~min} /$ day. In the middle of lactation, the average chewing time (Devries et al., 2009) averaged $555 \mathrm{~min} /$ day. In addition, Kaufman et al. (2018) reported a medium relationship between milk production at the beginning of lactation and the time spent chewing.

A strong correlation between daily milk production and lactation order has been confirmed by other authors (Hart et al., 2013; Vijayakumar et al., 2017). These authors confirmed that there is an increase in milk production until the third lactation. This also corresponds to our results, resp. the difference between heifers and multiparous dairy cows. However, for example, Mellado et al. (2011) in their study observed an increase in the amount of milk yield up to 6 lactations. However, our study does not confirm this. Hart et al. (2013) observed a difference in the milk yield of multiparous dairy cows and heifers in favor of multiparous cow $+20 \%$ of production.

The effect of the season has a significant effect on the feed intake and daily milk production parameters evaluated by us. Negative changes in chewing parameters are attributed by other authors to the heat stress that dairy cows suffer during the summer months (VI-VIII), when on average dairy cows chewed the shortest time in our work (Dado and Allen, 1994; Acatinai et al., 2010; Bernabucci et al., 2010; Soriani et al., 2013, Moretti et al., 2017). In contrast, in the winter (XII-II), dairy cows chewed in our work for a long time, which is agreed with other studies. A longer chewing time is was reported by Acatinai et al. (2010) and MüschnerSiemens et al. (2020) for the reason that the dairy cow does not suffer from heat stress. Furthermore, a similar period of chewing during spring and autumn in our work can be explained by similar climatic conditions, both in terms of thermal stress, when there is no crossing of the thermoneutral zone, and in terms of length of the day.

\section{CONCLUSION}

The results we obtained show a significant effect of breeding affiliation (or degree of hybridization), the lactation number and season on the daily length of eating, chewing, physical increased activity and the total duration of activities. The results we obtained, both independently and within the interactions, activities of dairy cows with the help of Vitalitmeters 5P, which in the future can bring not only valuable information for breeders, but also significantly improvement and simplification of the entire herd management.

Acknowledgements

The study was supported from the „„” grant of MŠMT ČR and projekt NAZV QK1910242.

\section{REFERENCES}

ACATINAI, S., GAVOJDIAN, D., STANCIU, G., TOMA CZISZTER, L., TRIPON, I. and BAUL, S. 2010. Study Regarding Rumination Behavior in Cattle-Position Adopted by Cows During Rumination Process. Animal Science and Biotechnologies, 43(2): 199-202.

ANGRECKA, S. and HERBUT, P. 2015. Conditions for cold stress development in dairy cattle kept in free stall barn during severe frosts. Czech Journal of Animal Science, 60(2): 81-87.

ANTANAITIS, R., ŽILAITIS, V., JUOZAITIENE, V., NOREIKA, A. and RUTKAUSKAS, A. 2018. Evaluation of rumination time, subsequent yield, and milk trait changes dependent on the period of lactation and reproductive status of dairy cows. Polish Journal of Veterinary Sciences, 21(3): 567-572.

AZIZI, O., HASSELMANN, L. and KAUFMANN, O. 2010. Variations in feeding behaviour of highyielding dairy cows in relation to parity during early to peak lactation. Archives Animal Breeding, 53(2): 130-140. 
AZIZI, O., KAUFMANN, O. and HASSELMANN, L. 2009. Relationship between feeding behaviour and feed intake of dairy cows depending on their parity and milk yield. Livestock Science, 122(2-3): 156-161.

BEAUCHEMIN, K. A. 1991. Ingestion and mastication of feed by dairy cattle. The Veterinary Clinics of North America: Food Animal Practice, 7(2): 439-463.

BEAUCHEMIN, K. A. 2018. Invited review: Current perspectives on eating and rumination activity in dairy cows. Journal of Dairy Science, 101(6): 4762-4784.

BEAUCHEMIN, K. A. and RODE, L. M. 1994. Compressed Baled Alfalfa Hay for Primiparous and Multiparous Dairy Cows. Journal of Dairy Science, 77(4): 1003-1012.

BERNABUCCI, U., LACETERA, N., BAUMGARD, L. H., RHOADS, R. P., RONCHI, B. and NARDONE, A. 2010. Metabolic and hormonal acclimation to heat stress in domesticated ruminants. Animal, 4(7): 1167-1183.

ČERNÝ, T., VEČĚ̌A, M., FALTA, D. and CHLÁDEK, G. 2016. The effect of the season on the behavior and milk yield of the Czech fleckvieh cows. Acta Universitatis Agriculturae et Silviculturae Mendelianae Brunensis, 64(4): 1125-1130.

DADO, R. G. and ALLEN, M. S. 1994. Variation in and Relationships Among Feeding, Chewing, and Drinking Variables for Lactating Dairy Cows. Journal of Dairy Science, 77(1): 132-144.

DEVRIES, T. J., BEAUCHEMIN, K. A., DOHME, F. and SCHWARTZKOPF-GENSWEIN, K. S. 2009. Repeated ruminal acidosis challenges in lactating dairy cows at high and low risk for developing acidosis: Feeding, ruminating, and lying behavior. Journal of Dairy Science, 92(10): 5067-5078.

HART, K. D., MCBRIDE, B. W., DUFFIELD, T. F. and DEVRIES, T. J. 2013. Effect of milking frequency on the behavior and productivity of lactating dairy cows. Journal of Dairy Science, 96(11): 6973-6985.

HIROOKA, H. and BHUIYAN, A. K. F. H. 1995. Additive and heterosis effects on milk yield and birth weight from crossbreeding experiments between holstein and the local breed in Bangladesh. Asian-Australasian Journal of Animal Sciences, 8(3): 295-300.

KARACAÖREN, B., JAFFRÉZIC, F. and KADARMIDEEN, H. N. 2006. Genetic parameters for functional traits in dairy cattle from daily random regression models. Journal of Dairy Science, 89(2): 791-798.

KAUFMAN, E. I., ASSELSTINE, V. H., LEBLANC, S. J., DUFFIELD, T. F. and DEVRIES, T. J. 2018. Association of rumination time and health status with milk yield and composition in early-lactation dairy cows. Journal of Dairy Science, 101(1): 462-471.

KOWSAR, R., GHORBANI, G. R., ALIKHANI, M., KHORVASH, M. and NIKKHAH, A. 2008. Corn silage partially replacing short alfalfa hay to optimize forage use in total mixed rations for lactating cows. Journal of Dairy Science, 91(12): 4755-4764.

KRPALKOVA, L., CABRERA, V. E., KVAPILIK, J. and BURDYCH, J. 2016. Dairy farm profit according to the herd size, milk yield, and number of cows per worker. Agricultural Economics (Czech Republic), 62(5): 225-234.

MAEKAWA, M., BEAUCHEMIN, K. A. and CHRISTENSEN, D. A. 2002. Effect of concentrate level and feeding management on chewing activities, saliva production, and ruminal $\mathrm{pH}$ of lactating dairy cows. Journal of Dairy Science, 85(5): 1165-1175.

MELLADO, M., ANTONIO-CHIRINO, E., MEZA-HERRERA, C., VELIZ, F. G., AREVALO, J. R., MELLADO, J. and DE SANTIAGO, A. 2011. Effect of lactation number, year, and season of initiation of lactation on milk yield of cows hormonally induced into lactation and treated with recombinant bovine somatotropin. Journal of Dairy Science, 94(9): 4524-4530.

MORETTI, R., BIFFANI, S., CHESSA, S. and BOZZI, R. 2017. Heat stress effects on Holstein dairy cows' rumination. Animal, 11(12): 2320-2325.

NOVÁK, P., ZABLOUDIL, F., ŠOCH, M. and VENGLOVSKÝ, J. 2000. Stable nvironment-significant factor for the welfare and productivity of cows. In: Proc. X Int. Congress on Animal Hygiene, Maastricht, The Netherlands. Volume 2, Animal Health Service. Boxtel, the Netherlands, pp. 1019-1024.

SORIANI, N., PANELLA, G. and CALAMARI, L. 2013. Rumination time during the summer season and its relationships with metabolic conditions and milk production. Journal of Dairy Science, 96(8): 5082-5094.

STONE, A. E., JONES, B. W., BECKER, C. A. and BEWLEY, J. M. 2017. Influence of breed, milk yield, and temperature-humidity index on dairy cow lying time, neck activity, reticulorumen temperature, and rumination behavior. Journal of Dairy Science, 100(3): 2395-2403.

TOUŠOVÁ, R., DUCHÁČEK, J., STÁDNÍK, L., PTÁČEK, M. and POKORNÁ, S. 2017. Influence of temperature-humidity relations during years on milk production and quality. Acta Universitatis Agriculturae et Silviculturae Mendelianae Brunensis, 65(1): 211-218.

VIJAYAKUMAR, M., PARK, J. H., KI, K. S., LIM, D. H., KIM, S. B., PARK, S. M., JEONG, H. Y., PARK, B. Y. and KIM, T. I. 2017. The effect of lactation number, stage, length, and milking frequency on milk 
yield in Korean Holstein dairy cows using automatic milking system. Asian-Australasian Journal of Animal Sciences, 30(8): 1093-1098.

WEST, J. W., MULLINIX, B. G. and BERNARD, J. K. 2003. Effects of Hot, Humid Weather on Milk Temperature, Dry Matter Intake, and Milk Yield of Lactating. Journal of Dairy Science, 86(1): 232-242.

Contact information

Radim Codl: codl@af.czu.cz

Jaromír Ducháček: duchacek@af.czu.cz

Jan Pytlík: pytlik@af.czu.cz

Luděk Stádník: stadnik@af.czu.cz

Mojmír Vacek: vacek@maf.czu.cz

Marek Vrhel: vrhel@af.czu.cz 